\title{
PENGARUH LAJU SEDIMENTASI DENGAN KERAPATAN RUMPUT LAUT DI PERAIRAN BANDENGAN JEPARA
}

\author{
Maruli Albert H, Niniek Widyorini, Ruswahyuni ${ }^{l}$ \\ Program Studi Manajemen Sumberdaya Perairan, Jurusan Perikanan \\ Fakultas Perikanan dan Ilmu Kelautan, Universitas Diponegoro
}

\begin{abstract}
Abstrak
Perairan Pantai Bandengan Jepara terletak di daerah utara Pulau Jawa. Jenis biota yang ada beragam dengan populasi masing-masing jenis. Penelitian ini bertujuan untuk mengetahui kerapatan rumput laut, nilai laju sedimentasi pada daerah rumput laut serta mengetahui hubungan perbedaan kerapatan rumput laut dengan laju sedimentasi di perairan bandengan Jepara. Materi yang digunakan dalam penelitian ini adalah komunitas rumput laut yang dibagi menjadi 3 pengambilan, pengambilan dilakukan secara tegak lurus ke arah laut dan penghitungan laju sedimentasi dengan menggunakan sedimen trap yang di pasang pada lokasi tersebut. Metode yang digunakan dalam penelitian adalah metode survey. Metode penentuan kerapatan rumput laut dilakukan dengan frame kuadran ukuran 1x1 m dengan cara menghitung jumlah tegakan rumput laut dalam setiap meter persegi sepanjang $100 \mathrm{~m}$. Kerapatan rumput laut di perairan Bandengan Jepara di dapat 431 individu/300m ${ }^{2}$ yang terdapat 9 jenis dari 2 filum yaitu Filum Chlorophyta : Halimeda opuntia sebanyak 157 individu/300m ${ }^{2}$, Halimeda descoides sebanyak 58 individu/300 $\mathrm{m}^{2}$, Halimeda makroloba sebanyak 74 individu/300m ${ }^{2}$, filum Phaeophyta : Chordoria flagelliformis sebanyak 31 individu $/ 300 \mathrm{~m}^{2}$, Padina crassa sebanyak 83 individu $/ 300 \mathrm{~m}^{2}$, Sargassum yendoi sebanyak 15 individu $/ 300 \mathrm{~m}^{2}$, Sargassum piluliferum sebanyak 3 individu $/ 300 \mathrm{~m}^{2}$, Sargassum confusum sebanyak 5 individu $/ 300 \mathrm{~m}^{2}$, dan Sargassum duplicatum sebanyak 5 individu $/ 300 \mathrm{~m}^{2}$. Hasil penghitungan laju sedimentasi diketahui rata-rata laju sedimentasi pada lokasi penelitian adalah $0,85 \mathrm{mg} / \mathrm{cm} 3 /$ hari. Nilai korelasi antara laju sedimentasi dengan kerapatan rumput laut sebesar 0,85, hal ini menunjukkan bahwa adanya hubungan yang erat antara laju sedimentasi dengan kerapatan rumput laut di perairan Bandengan, Jepara.
\end{abstract}

Kata Kunci : laju sedimentasi, kerapatan rumput laut, Bandengan Jepara.

Coastal waters Bandengan Jepara is located in the area north of the island of Java. Type diverse biota with a population of each type. The purpose of this research is to know the density of sea grass, the value of the rate of sedimentation in the area and know the relationship seaweed kelp density differences in the rate of sedimentation in the waters Bandengan Jepara. This research was conducted during the month of March 2013 in Bandengan Jepara. The material used in this study is the seaweed community that is divided into 3 decision, the decision is done perpendicular to the direction of the sea and the counting rate of sedimentation by using sediment traps were installed at that location. The method used in the study is a survey method. The method to determine the density of sea grass made with frame size $1 \times 1$ $\mathrm{m}$ quadrants by calculating the amount of seaweed stands in each square meter along the $100 \mathrm{~m}$. Density of seaweed in the waters in Jepara Bandengan can individu/300m2 contained 43192 types of the phylum Chlorophyta Phylum: Halimeda opuntia at 157 individu/300m2, as much as 58 individu/300m2 Halimeda descoides, Halimeda makroloba by 74 individu/300m2, phylum Phaeophyta : Chordoria flagelliformis by 31 individu/300m2, Padina crassa by 83 individu/300m2, Sargassum yendoi many as 15 individu/300m2, Sargassum piluliferum much as 3 individu/300m2, Sargassum confusum individu/300m 2 much as 5 and as many as 5 individu/300m2 Sargassum duplicatum. Sedimentation rate calculation results are known the average rate of sedimentation at the study site was $0.85 \mathrm{mg} / \mathrm{cm} 3 /$ day. The correlation value between rate of sedimentation and the seagrass density is 0.85 . This indicate that there is have relationship between rate of sedimentation and seagrass density in the Bandengan, Jepara.

Keywords :Sedimentation rate, seagrass density, Bandengan Jepara.

*) Penulis Penanggung Jawab 


\section{PENDAHULUAN}

Pantai Bandengan merupakan pantai di pesisir utara Jawa (pantura) yang terletak di utara Kabupaten Jepara, Jawa Tengah. Kabupaten Jepara memiliki potensi sumberdaya perikanan yang besar, hal ini dapat dilihat dengan keberadaan garis pantai Jepara yang panjangnya mencapai $72 \mathrm{Km}$.

Rumput laut merupakan tanaman makro alga yang hidup di laut yang tidak memiliki akar, batang, dan daun sejati. Umumnya rumput laut hidup di dasar perairan. Rumput laut disebut tanaman karena memiliki klorofil (zat hijau daun) sehingga bisa berfotosintesis. Rumput laut sering disebut sebagai alga atau ganggang pada daerah - daerah tertentu di Indonesia. Tumbuhan perairan ini bersifat unicellulair (sel satu) maupun multicellulair (bersel banyak) dan tidak tergantung pada tumbuhan lain. Rumput laut dimanfaatkan secara luas baik dalam bentuk raw material maupun dalam bentuk hasil olahan. Di Indonesia makroalga digunakan sebagai lalapan, obat, manisan, dan sayuran. Sedangkan di Jepang digunakan sebagai sayuran, minuman teh, dan campuran pada nasi. Selain itu, pemanfaatan makroalga adalah sebagai pupuk, makanan ternak, dan sumber energi (Susanto, 2000).

Rumput laut merupakan tumbuhan air yang tumbuh pada tingkat kedalaman yang berbeda-beda selama cahaya matahari masih dapat masuk ke dalam perairan dan dipengaruhi oleh arus dalam proses penyebarannya di perairan. Pentingnya pengkajian mengenai pengaruh laju sedimentasi di daerah rumput laut diharapkan dapat mengetahui keanekaragaman rumput laut serta dampak yang terjadi apabila laju sedimentasi tersebut tinggi atau rendah.

\section{MATERI DAN METODE}

Penelitian dilaksanakan pada bulan Maret 2013 di perairan Bandengan, Jepara. Materi yang digunakan dalam penelitian ini adalah sedimen dan rumput laut. Metode yang digunakan adalah metode observasi, yaitu metode yang dilakukan dengan pengamatan dan pencatatan secara sistematis mengenai kejadian-kejadian yang diselidiki dalam suatu penelitian dan hasilnya menggambarkan sifat populasi dari objek penelitian. Metode yang digunakan pada pengambilan data adalah kuadran transek. Pengamatan dilakukan secara tegak lurus dari garis pantai sepanjang 100 meter. Pengamatan dilakukan dengan mencatat jenis rumput laut serta tutupan rumput laut yang ditemukan dalam tiap luasan kuadran transek. Sampel rumput laut yang diambil dari lokasi penelitian kemudian dilakukan identifikasi. Pada transek garis yang sudah ditentukan, dilakukan pengukuran terhadap variabel kualitas lingkungan.

Pengukuran laju sedimentasi dilakukan dengan memasang sediment trap mengikuti King (1975) yang dibuat dari pipa paralon yang berdiameter $5 \mathrm{~cm}$ dengan tinggi $10 \mathrm{~cm}$. Diletakan 4 buah sediment trap sebagai ulangan. Pengambilah contoh sedimen dilakukan selama 1 bulan. Kemudian sampel sedimen yang didapatkan dikeringkan selanjutnya dilakukan pengukuran berat sedimen untuk selanjutnya dianalisis laju sedimentasi dalam satuan $\mathrm{mg} / \mathrm{cm}^{3} /$ hari.

Metode yang digunakan dalam analisa data pada penelitian ini adalah:

Kerapatan jenis rumput laut

Mencatat semua jenis dan jumlah masing-masing dalam bentuk individu maupun koloni dan menghitung kerapatan relatif setiap jenis dalam satu komunitas dengan rumus:

\section{Penutupan jenis rumput laut}

$$
K R=\frac{\text { Jumlah individu jenis A }}{\text { Jumlah individu seluruh jenis }} \times 100 \%
$$

Mengukur luas dasar yang tertutup tumbuhan dengan cara mengukur luas koloni atau individu. Kemudian dinyatakan dalam prosen penutupan relatif masing-masing spesies per meter persegi dengan:

\section{Frekuensi penyebaran rumput laut}

$$
P R=\frac{\text { Penutupan individu jenis A }}{\text { Jumlah penutupanseluruh jenis }} \times 100 \%
$$

Menghitung berapa kali kehadiran jenis tertentu kedalam seluruh plot dalam suatu komunitas kemudian menyatakan dalam prosen. Frekuensi relatif tiap jenis dalam suatu komunitas per meter persegi dengan:

\section{KR, PR, dan FR}

$$
F R=\frac{\text { Frekuensi jenis A }}{\text { Frekuensi seluruh jenis }} \times 100 \%
$$

Setelah diperoleh harga-harga KR, PR, FR, Selanjutnya menghitung beberapa nilai berikut ini:

Nilai Penting (NP)

Nilai penting dapat dihitung dengan rumus: $\mathrm{NP}=\mathrm{KR}+\mathrm{PR}+\mathrm{FR}$ 


\section{Sedimentasi}

Laju sedimentasi dinyatakan dalam $\mathrm{mg} / \mathrm{cm}^{2} / \mathrm{hari}^{1}$ (Kharkar et al. 1968). Pengamatan dilakukan dengan mengoleksi sedimen yang terperangkap dalam sedimen traps yang dipasang selama 30 hari. Selanjutnya dihitung berat kering sedimen (dalam mg) dengan menggunakan timbangan analitik.

Perhitungan Laju sedimentasi dilakukan melalui persamaan seperti berikut :

Keterangan :

$$
L S=\frac{B S}{\text { Jumlah hari } x t \pi r^{2}}
$$

$L S=$ laju sedimentasi $\left(\mathrm{mg} / \mathrm{cm}^{3} /\right.$ hari $)$

$B S=$ berat kering sedimen $(\mathrm{mg})$

$\pi=3,14$

$r \quad=$ jari - jari lingkaran sedimen traps $(\mathrm{cm})$

$t=$ tinggi sedimen trap $(\mathrm{cm})$

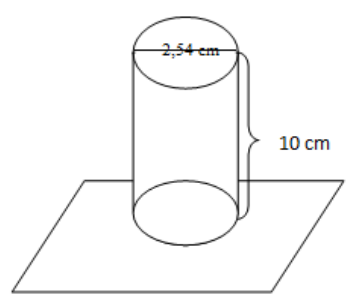

Gambar 1. Sedimen trap

HASIL

a. Kelimpahan dan Komposisi Rumput Laut

Hasil pengamatan kelimpahan dan komposisi rumput laut disajikan pada Tabel 1 dibawah ini :

\begin{tabular}{clcccccc}
\hline No & \multicolumn{1}{c}{ Spesies } & $\mathrm{Ki}$ & $\mathrm{KR} \%$ & $\mathrm{Pi}$ & $\mathrm{PR} \%$ & $\mathrm{Fi}$ & $\mathrm{FR} \%$ \\
\hline 1 & Halimeda opuntia & 157 & 36,42 & 866 & 25,41 & 50 & 29,58 \\
2 & Padina crassa & 83 & 19,25 & 687 & 20,15 & 31 & 18,34 \\
3 & Halimeda makroloba & 74 & 17,17 & 569 & 16,69 & 30 & 17,75 \\
4 & Halimeda descoides & 58 & 13,45 & 344 & 10,09 & 18 & 10,65 \\
5 & Chordoria flagelliformis & 31 & 7,19 & 279 & 8,18 & 19 & 11,24 \\
6 & Sargassum yendoi & 15 & 3,48 & 363 & 10,65 & 9 & 5,32 \\
7 & Sargassum duplicatum & 5 & 1,16 & 110 & 3,23 & 5 & 2,96 \\
8 & Sargassum confusum & 5 & 1,16 & 100 & 2,93 & 4 & 2,36 \\
9 & Sargassum piluliferum & 3 & 0,69 & 90 & 2,64 & 3 & 1,77 \\
\hline
\end{tabular}

Didapatkan 9 spesies rumput laut yaitu Halimeda opuntia, Padina crassa, Halimeda makroloba, Halimeda descoides, Chordoria flagelliformis, Sargassum yendoi, Sargassum duplicatum, Sargassum confusum, dan Sargassum piluliferum. Berdasarkan Tabel 1 di atas, didapatkan diagram histogram dari jenis individu rumput laut yang disajikan pada gambar dibawah ini :

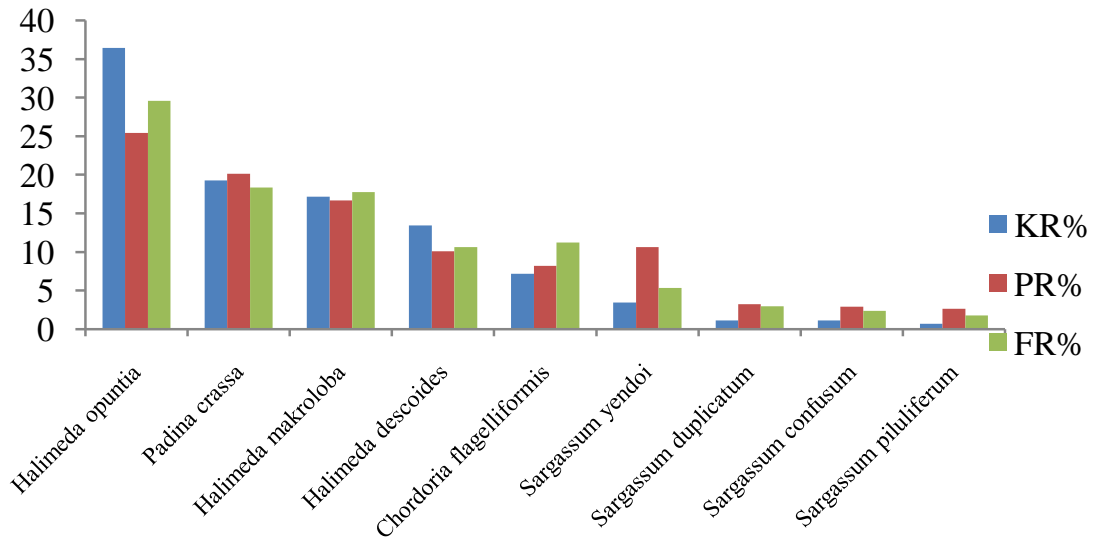

Gambar 3. Histogram persentase kerapatan rumput laut di perairan Bandengan Jepara. 
Berdasarkan Tabel 1 dan histogram diatas dapat diketahui pada lokasi tersebut diperoleh hasil yaitu jenis yang termasuk dalam filum chlorophyta yaitu Halimeda opuntia ditemukan sebanyak 157 individu $/ 300 \mathrm{~m}^{2}$, Halimeda descoides ditemukan sebanyak 58 individu/300 ${ }^{2}$, Halimeda makroloba ditemukan sebanyak 74 individu $/ 300 \mathrm{~m}^{2}$, sedangkan yang termasuk dalam filum phaeophyta yaitu Chordoria flagelliformis ditemukan sebanyak 31 individu/ $300 \mathrm{~m}^{2}$, Padina crassa ditemukan sebanyak 83 individu $/ 300 \mathrm{~m}^{2}$, Sargassum yendoi ditemukan sebanyak 15 individu $/ 300 \mathrm{~m}^{2}$, Sargassum piluliferum ditemukan sebanyak 3 individu $/ 300 \mathrm{~m}^{2}$, Sargassum confusum ditemukan sebanyak 5 individu/300 $\mathrm{m}^{2}$ dan Sargassum duplicatum ditemukan sebanyak 5 individu $/ 300 \mathrm{~m}^{2}$.

b. Nilai Penting Rumput Laut

Hasil persentase nilai penting kerapatan rumput laut dapat dilihat pada Tabel 2 berikut:

\begin{tabular}{clcc}
\hline No & \multicolumn{1}{c}{ Jenis } & Nilai Penting & Persentase \\
\hline 1. & Halimeda opuntia & 91,41 & 30,47 \\
2. & Padina crassa & 57,74 & 19,25 \\
3. & Halimeda makroloba & 51,61 & 17,20 \\
4. & Halimeda descoides & 34,19 & 11,39 \\
5. & Chordoria flagelliformis & 26,61 & 8,87 \\
6. & Sargassum yendoi & 19,45 & 6,48 \\
7. & Sargassum duplicatum & 7,35 & 2,45 \\
8. & Sargassum confusum & 6,45 & 2,15 \\
9. & Sargassum piluliferum & 5,1 & 1,7 \\
\hline \multicolumn{4}{c}{} \\
\hline
\end{tabular}

Dari Tabel 2 diatas dapat dilihat persentase nilai penting dari Halimeda opuntia ditemukan sebesar 30,47\%, Padina crassa sebesar 19,25\%, Halimeda makroloba sebesar 17,20\%, Halimeda descoides sebesar $11,39 \%$, Chordoria flagelliformis sebesar 8,87\%, Sargassum yendoi sebesar 6,48\%, Sargassum duplicatum sebesar 2,45\%, Sargassum confusum sebesar 2,15\% dan Sargassum piluliferum sebesar 1,7\%

c. Kelimpahan Meiofauna

Hasil laju sedimentasi $\left(\mathrm{mg} / \mathrm{cm}^{3} /\right.$ hari) yang diperoleh tersaji pada Tabel 3 di bawah ini.

\begin{tabular}{cccc} 
Line 1 & Line 2 & Line 3 & Rata - rata \\
\hline 0,76 & 0,85 & 0,93 & 0,85 \\
\hline
\end{tabular}

Dari Tabel 3 diatas dapat dilihat laju sedimentasi pada pengulangan pertama sebesar $0,76 \mathrm{mg} / \mathrm{cm}^{3} / \mathrm{hari}$, pengulangan kedua sebesar $0,85 \mathrm{mg} / \mathrm{cm}^{3} /$ hari, pengulangan ketiga sebesar $0,93 \mathrm{mg} / \mathrm{cm}^{3} / \mathrm{hari}$, sehingga didapatkan rata-rata laju sedimentasi pada lokasi tersebut sebesar $0,85 \mathrm{mg} / \mathrm{cm}^{3} / \mathrm{hari}$.

\section{d. Parameter Fisika dan Kimia Perairan}

Pengukuran parameter fisika dan kimia dilakukan pada saat sampling dengan hasil pengukuran yang didapatkan seperti pada Tabel 5 dibawah ini:

\begin{tabular}{|c|c|c|c|c|c|c|}
\hline \multirow{2}{*}{ Parameter } & \multirow{2}{*}{ Satuan } & \multicolumn{3}{|c|}{ Nilai pengamatan di lokasi } & \multirow{2}{*}{ Nilai optimum } & \multirow{2}{*}{ Pustaka } \\
\hline & & 1 & 2 & 3 & & \\
\hline Suhu air & ${ }^{\mathrm{O}} \mathrm{C}$ & $28-29$ & $28-29$ & $28-29$ & $28-30$ & Dahuri, 2003 \\
\hline Salinitas & $\%$ & 31 & 31 & 31 & $29-34$ & Alongi, 1998 \\
\hline Kec Arus & $\mathrm{m} / \mathrm{s}$ & $0,03-0,08$ & $0,03-0,09$ & $0,04-0,1$ & $0,01-0,33$ & Trono, 1988 \\
\hline Kecerahan & $\mathrm{Cm}$ & $\begin{array}{c}\text { Sampai } \\
\text { dasar }\end{array}$ & $\begin{array}{c}\text { Sampai } \\
\text { dasar }\end{array}$ & $\begin{array}{l}\text { Sampai } \\
\text { dasar }\end{array}$ & 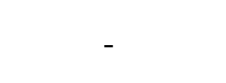 & Alongi, 1998 \\
\hline Kedalaman & $\mathrm{M}$ & $0,15-0,60$ & $0,65-1,00$ & $1,00-1,30$ & Sd 20 & Alongi, 1998 \\
\hline DO & $\mathrm{mg} / \mathrm{l}$ & 4,8 & 4,2 & 4 & $3,5-6,0$ & Hutabarat, 2000 \\
\hline
\end{tabular}

Berdasarkan Tabel 5 tersebut dapat dilihat suhu pada pengulangan 1, 2 dan 3 berkisar antara $28-29^{\circ} \mathrm{C}$, salinitas berkisar antara 31\%o, untuk kedalaman berkisar antara 0,15-1.30 meter, sedangkan untuk kecerahan pada ke tiga pengulangan tersebut tidak terhingga (dasar perairan terlihat), dan untuk kecepatan arus berkisar antara $0,03-0,1 \mathrm{~m} /$ detik, serta oksigen terlarut (DO) berkisar antara 4 - 4,8 mg/l. 
e. Hubungan Laju Sedimetasi dengan Kerapatan Rumput Laut

Pada Uji Korelasi didapatkan nilai sebesar 0,85 $(>0,05)$ dengan asumsi $\mathrm{H}_{1}$ diterima dan $\mathrm{H}_{0}$ ditolak. Hal ini menunjukkan bahwa adanya hubungan antara laju sedimentasi dengan kerapatan rumput laut di perairan Bandengan, Jepara. Nilai korelasi antara laju sedimentasi dengan kerapatan rumput laut di perairan Bandengan, Jepara sebesar 0,85 yang menunjukkan bahwa adanya hubungan yang erat antara laju sedimetasi dengan kerapatan lamun yang berbeda di perairan Bandengan, Jepara.

\section{PEMBAHASAN}

Hasil pengamatan di perairan bandengan, Jepara dapat dilihat dari tabel 1. Hasil jenis rumput laut yang ditemukan di lokasi sampling ditemukan 9 jenis yaitu Halimeda opuntia, Halimeda descoides, Halimeda makroloba, Chordoria flagelliformis, Padina crassa, Sargassum yendoi, Sargassum piluliferum, Sargassum confusum, dan Sargassum duplicatum. Berdasarkan tabel 1, jenis yang banyak ditemukan adalah Halimeda opuntia. Kerapatan, penutupan maupun frekuensi dari Halimeda opuntia paling tinggi yaitu 36,42\% untuk kerapatan relatif, $25,41 \%$ untuk penutupan relatif dan $29,58 \%$ untuk frekuensi relatif. Halimeda opuntia merupakan Alga hijau yang merupakan kelompok terbesar dari vegetasi alga. Alga hijau berbeda dengan divisi lainnya karena memiliki warna hijau yang jelas seperti tumbuhan tingkat tinggi karena mengandung pigmen klorofil a dan klorofil b lebih dominan dibandingkan karoten dan xantofil. Selain itu, Halimeda opuntia memiliki kerapatan yang tertinggi dikarenakan substrat dasar di perairan tersebut banyak di dominasi oeh jenis pasir dan pecahan karang. Menurut Kordi (2010), alga hijau biasa ditemukan pada jenis substrat pasir, pecahan karang dan karang mati, serta mampu meningkatkan produktivitas di perairan tersebut.

Sedangkan secara akumulatif rata-rata laju sedimentasi pada lokasi tersebut adalah $0,85 \mathrm{mg} / \mathrm{cm}^{3} / \mathrm{hari}$. Kecepatan endapan sedimen tersebut tergolong level rendah. Menurut Supriharyono (2000) Perkiraan dampak level sedimentasi, digolongkan dalam tiga dampak yaitu kecil - sedang bila laju sedimentasi 1-10 $\mathrm{mg} / \mathrm{cm}^{3} /$ hari, kategori sedang-bahaya bila laju sedimentasi $10-50 \mathrm{mg} / \mathrm{cm}^{3} /$ hari, kategori sangat bahaya bila laju telah melebihi $50 \mathrm{mg} / \mathrm{cm} 3 /$ hari. kondisi laju sedimentasi tersebut masih baik bagi pertumbuhan rumput laut. Pengaruh laju sedimentasi di perairan tersebut dapat berdampak baik dan buruk, karena fungsi sedimentasi membawa unsur - unsur hara di perairan yang dibawa oleh arus kemudian dapat dimanfaatkan oleh komunitas rumput laut untuk pertumbuhan serta produktivitas dalam perairan tersebut, apabila laju sedimentasi yang tinggi maka perairan akan mengalami kekeruhan dan berdampak mengurangi kelimpahan dari biota tersebut.

Hasil pengukuran parameter fisika dan kimia pada lokasi sampling didapatkan, pengukuran suhu air yang ideal $\left(28-29^{\circ} \mathrm{C}\right)$. Hutabarat dan Evans (1985) mengatakan bahwa kisaran temperatur di semua perairan Indonesia yang merupakan daerah tropis adalah relatif sama. Menurut Dahuri (2003) kisaran optimum temperatur untuk pertumbuhan biota adalah $26-30^{\circ} \mathrm{C}$.

Hasil pengukuran salinitas di lokasi penelitian berada pada kisaran 31\% Menurut Aslan (1998), kesuburan alga atau rumput laut dipengaruhi oleh kadar garam atau salinitas perairan tersebut dan salinitas optimum untuk kehidupan rumput laut berkisar antara $29-34 \%$.

Pada pengukuran kecepatan arus didapatkan besarnya kecepatan arus pada lokasi penelitian 0,03 sampai $0,1 \mathrm{~m} / \mathrm{s}$. Aslan (1998) menyatakan bahwa arus merupakan faktor pembatas dalam penyebaran spora, pelekatan dan pertumbuhan rumput laut, hal ini dikarenakan zat hara yang ada di perairan dibawa oleh arus, sehingga zat hara diperairan dapat tersebar dan gerakan air mempengaruhi melekatnya spora pada substratnya. Kisaran arus untuk pertumbuhan rumput laut di perairan berkisar antara 0,01-0,33 m/s.

Kecerahan pada lokasi tersebut memiliki kecerahan yang tinggi yaitu sampai dasar perairan, dan kedalaman pada lokasi tersebut berkisar 30-145 cm. Nilai kecerahan dan kedalaman yang diperoleh saat penelitian menunjukan bahwa cahaya matahri masih dapat menembus hingga dasar perairan.menurut Perkins (1974) menyatakan bahwa Rumput laut sangat membutuhkan sinar matahari yang cukup untuk melakukan proses fotosintesis di perairan, dan adanya kekeruhan pada perairan yang terjadi secara terus menerus dapat menyebabkan penetrasi cahaya yang masuk berkurang dan bisa mengakibatkan kematian pada biota tersebut.

Hasil pengukuran DO pada lokasi tersebut berkisar antara 4- 4,8 mg/l. Menurut Odum (1971), kisaran DO yang ada pada suatu perairan berkisar antara 3,5-6 mg/l, sehingga dapat dikatakan bahwa kisaran DO pada lokasi penelitian masih layak bagi kehidupan organisme di perairan tersebut.

Hasil analisa uji korelasi didapatkan nilai sebesar $0,75(\geq 0,05)$, dengan kesimpulan $\mathrm{H}_{0}$ diterima dan $\mathrm{H}_{1}$ ditolak yaitu ada hubungan antara laju sedimentasi dengan kerapatan rumput laut di perairan Bandengan, Jepara. Selain itu, didapatkan nilai korelasi antara laju sedimentasi dengan kerapatan rumput laut sebesar 0,85 . Hasil ini menunjukkan adanya pengaruh dan hubungan yang erat antara laju sedimentasi dengan kerapatan rumput laut di perairan Bandengan, Jepara.

\section{KESIMPULAN}

Berdasarkan hasil penelitian yang diperoleh, bahwa kerapatan rumput laut terdapat 431 individu $/ 300 \mathrm{~m}^{2}$ yang terdiri dari Halimeda opuntia, Padina crassa, Halimeda makroloba, Halimeda descoides, Chordoria flagelliformis, Sargassum yendoi, Sargassum dupicatum, Sargassum confusum dan 
Sargassum piluliferum. Sedangkan nilai rata-rata laju sedimentasi pada lokasi tersebut masih tergolong kecil yaitu $0,85 \mathrm{mg} / \mathrm{cm} 3 /$ hari.

Dari hasil Uji Korelasi menunjukkan bahwa adanya pengaruh dan hubungan yang erat antara kerapatan rumput laut dengan laju sedimentasi di Bandengan, Jepara.

\section{SARAN}

Perlu dilakukan lanjutan mengenai laju sedimentasi di perairan Bandengan, Jepara.dengan rentang waktu pengambilan sampel yang lebih lama dan jarak stasiun yang lebih menyebar sehingga pengamatan dapat meliputi seluruh perairan tersebut dan akan memberi kelengkapan informasi tentang hubungan antara kerapatan rumput laut dengan laju sedimentasi.

\section{Ucapan Terimakasih}

Pada kesempatan ini penulis mengucapkan banyak terimakasih kepada Ir. Ruswahyuni MSc dan Dra. Niniek Widyorini, MS. yang telah membimbing dan membantu dalam penyusunan penulisan ini, serta keluarga dan teman-teman yang turut berpartisipasi dalam penelitian dan terus memberikan dukungan.

\section{DAFTAR PUSTAKA}

Alongi, D. M. 1998. Coastal Ecosystem Process. CRC Press. New York. 419pp

Aslan,M.1998. Rumput Laut. Penerbit Kanisius. Yogyakarta.

Dahuri, R.J. Rais, S.P. Ginting dan M.J. Sitepu. 2003. Pengelolaan Sumberdaya Wilayah Pesisir dan Lautan Secara Terpadu. PT.Pradnya Paramita. Jakarta. $305 \mathrm{hlm}$.

Hutabarat, S dan Evans. 1985. Pengantar Oceanografi. Undip Press. Semarang. $157 \mathrm{hlmn}$

Kharkar, D.P., K.K. Turekian, and K.K Bertine. 1968. Stram supply of dissolved silver, molybdenum, antimony, selenium, chromium, cobalt, rubidium and cesium to the oceans. Geochim. Cosmochim. Acta.,32:285-298.

King, C.M. 1975. Introduction to marine geology and geomorphology. Arnold, London,370p.

Kordi, K. 2010. A to Z Budidaya Biota Akuatik Untuk Pangan, Kosmetik, dan Obat-obatan. Penerbit ANDI. Yogyakarta

Odum, E.P. 1971. Fundamental of Ecology. WB Sounders Company, Philadelpia. 574 pp.

Perkins, J. 1974. The Biology. Revised Edition. Reston Publishing Company Inc. Reston Virginia USA.

Santoso, S.2011. Mastering SPSS. PT. Elex Media Komputindo. Jakarta

Supriharyono. 2000. Pelestarian dan Pengelolaan Sumberdaya Alam di Wilayah Pesisir Tropis. PT Gramedia Pustaka Utama. Jakarta. $56 \mathrm{hlm}$.

Susanto, AB. 2000. Abalon dan Rumput Laut. Navila Idea. Jakarta.

Trono, J.R. 1988. Euchema Farming in The Philipines, UP. Natural Science Research Center, Quizon City. 